International Research Journal of Management, IT \& Social Sciences
Available online at https://sloap.org/journals/index.php/irjmis/
Vol. 9 No. 1, January 2022, pages: 110-118
ISSN: 2395-7492
https://doi.org/10.21744/irjmis.v9n1.2013

\title{
The Influence of Word of Mouth and Brand Image on the Consumer Decision Process in Choose Clinic Content
} (Case Study of Embun Pagi Sekayu Gynecological Clinic)

CrossMark
Rulli Ramadhayani B $^{\text {a }}$
Zakaria Wahab $^{\text {b }}$
Marlina Widiyanti $^{{ }^{2}}$
Aslamia Rosa $^{\mathrm{d}}$

Article history:

Submitted: 09 October 2021

Revised: 18 November 2021

Accepted: 27 December 2021

\section{Keywords:}

brand image;

clinic content;

consumer decision;

purchase decision;

word of mouth;

\begin{abstract}
This study aimed to analyze the effect of word of mouth and brand image jointly and partially on consumer decisions and the dominant two variables. Data collection at the Embun Pagi Clinic in the Sekayu area involved 100 patients who used the services of the Sekayu Embun Pagi Clinic with nonprobability sampling, namely accidental sampling. Data was collected by distributing questionnaires and using multiple linear regression using SPSS software. Data analysis is a descriptive method, classical assumption test with normality test with Kolmogorov-Smirnov, multiple regression analysis methods with $\mathrm{f}$ test, t-test, and coefficient of determination. This study indicates that word of mouth and brand image significantly influence the consumer decision process in choosing the Embun Pagi Sekayu Gynecological Clinic. These results can be seen in the multiple regression analysis and the coefficient of determination R-value of 0.802 , meaning that the relationship between word of mouth and brand image on consumer decisions is $80.2 \%$, meaning that the relationship between variables is close. Adjusted R Square value of 0.636 means that $63.6 \%$ of purchasing decision factors can be explained by word of mouth and brand image. At the same time, the remaining $36.4 \%$ can be explained by other factors not examined in this study, such as social factors.
\end{abstract}

International research journal of management, IT and social sciences (C) 2022. This is an open access article under the CC BY-NC-ND license (https://creativecommons.org/licenses/by-nc-nd/4.0/).

Corresponding author:

Rulli Ramadhayani B,

Master of Management, Sriwijaya University, Palembang, Indonesia.

Email address: rulli.ramadhayani21@gmail.com

\footnotetext{
Sriwijaya University, Palembang, Indonesia

Sriwijaya University, Palembang, Indonesia

Sriwijaya University, Palembang, Indonesia

Sriwijaya University, Palembang, Indonesia 


\section{Introduction}

The health sector today is one form of excellent business opportunity. The development can see this of private hospitals or clinics that were established. Although the spread of the construction of hospitals and clinics is classified as uneven in some areas, with the awareness of today's society which is increasingly critical and selective in deciding the use of a service to be purchased, it can strengthen the existence of the best choice for consumers to make their choice regarding the use of the service they will use.

Obstetrics and gynecology clinic 'Embun Pagi' Sekayu provides antenatal and gynecological services. This clinic is located right in the center of Sekayu city, namely Jalan Merdeka Sekayu Musi Banyuasin, which is the main street in the city. This obstetric clinic is quite attractive to patients, especially pregnant women or married couples who need consultation regarding pregnancy and childbirth and consultation on obstetrics and midwifery issues. In addition to having supporting facilities such as 4-dimensional ultrasound facilities that are used to determine the development of the fetus in pregnant women, they also provide pharmacy facilities to make it easier for patients to buy their medical needs. However, this Embun Pagi Gynecological Clinic does not provide inpatient facilities and operating rooms, so it is difficult for patients to take immediate action, such as giving birth or inpatient treatment (Meitridasari et al., 2021).

At Sekayu Hospital, the obstetrical examination service has not used 4-dimensional ultrasound, and this is something different and strength for the Embun Pagi clinic to create a better brand image; it can also attract patients at the RSUD who are not satisfied with the examination only with 2-dimensional ultrasound. This is different from Nurul Clinic, a competitor to the clinic. Embun Pagi, even though they have used 4-dimensional ultrasound, the cost of the examination is more expensive, so this is an advantage for the Embun Pagi Clinic, which provides more affordable prices for its patients (Sääksjärvi \& Samiee, 2011).

This clinic has only been running for three years, so it takes a solid effort to get customers. However, Embun Pagi Clinic has also obtained customers who were previously loyal to doctors at Sekayu Hospital. However, more efforts are still needed so that these customers are not only loyal to doctors but also loyal to the clinic. However, it must be acknowledged that nurses and midwives also carry out marketing by providing services that meet customer expectations (Mahatama \& Wardana, 2021).

Currently, the customers of this Embun Pagi Gynecology clinic have reached more than 1,000 customers, $10 \%$ of whom are young women and women over 40 years old and also come from outside the Sekayu area. Every month, this Embun Pagi Gynecology clinic has an average of up to 100 patients, either for routine consultations, doing ultrasounds, or just buying medicine. This success can be seen from the table of the number of patient visits at the Embun Pagi Sekayu clinic as follows:

Table 1

Data on the number of patients at Sekayu "Embun Pagi" Clinic

The year 2018-2020

\begin{tabular}{lccc}
\hline Month & 2018 & 2019 & 2020 \\
\hline January & 133 & 160 & 137 \\
February & 157 & 121 & 130 \\
March & 149 & 125 & 147 \\
April & 159 & 130 & 146 \\
May & 167 & 135 & 132 \\
June & 161 & 127 & 163 \\
July & 163 & 150 & 141 \\
August & 151 & 133 & 137 \\
September & 155 & 147 & 150 \\
October & 141 & 132 & 137 \\
November & 173 & 140 & 137 \\
December & 149 & 162 & 135 \\
Total & 1858 & 1662 & 1692 \\
\hline
\end{tabular}

Source: Gynecological Clinic "Embun Pagi" Sekayu, 2021

Table 1 above has provided information on the number of patient visits from 2018 to 2020 . When viewed from the intensity of patient visits from 2018 to 2020, the graph shows that the graph is not very stable because there has been a decrease in the number of patient visits in 2019, but in 2020 it increased visits with a total of 1692 patients. The

Ramadhayani B, R., Wahab, Z., Widiyanti, M., \& Rosa, A. (2022). The influence of word of mouth and brand image on the consumer decision process in choose clinic content: Case Study of Embun Pagi Sekayu Gynecological Clinic. International Research Journal of Management, IT and Social Sciences, 9(1), 110-118. https://doi.org/10.21744/irjmis.v9n1.2013 
increasing number of visits to a clinic is influenced by the value received by patients on the brand image. The brand image that is formed is the quality of doctors, affordable prices, and is supported by more complete facilities than Regional Hospitals, and coupled with the COVID-19 virus pandemic condition which causes patients to switch more to doing examinations at clinics which are felt to be safer and more comfortable than compared to others. Regional Hospital.

Table 2

Achievement of new and old patient visits at the "Embun Pagi” Gynecological Clinic - Sekayu 2018-2020

\begin{tabular}{|c|c|c|c|c|c|c|}
\hline \multicolumn{7}{|c|}{ Achievements Per Year } \\
\hline & \multicolumn{2}{|c|}{2018} & \multicolumn{2}{|c|}{ the year 2019} & \multicolumn{2}{|c|}{2020} \\
\hline & New Px & Old px & New Px & Old PX & New Px & Old px \\
\hline & 464 & 1394 & 352 & 1310 & 573 & 1119 \\
\hline Total Visits & \multicolumn{2}{|c|}{1858} & \multicolumn{2}{|c|}{1662} & \multicolumn{2}{|c|}{1692} \\
\hline Old Px Trend & - & - & - & Down & - & Down \\
\hline New Px Trend & - & - & Down & - & Ride & - \\
\hline
\end{tabular}

Source: Sekayu Embun Pagi Clinic Medical Record Report, 2021

In table 2, it can be learned that patient visits at the Embun Pagi Clinic in 2018 were 1858 people; in 2019, patient visits decreased to 1662 people, and in 2020 increased to 1692 people. The increase in patient visits in 2020 is not proportional to the large number of new patients who have increased. This is supported by the number of old patient visits in 2018 at the clinic of 1394 people; in 2019, old patient visits decreased by 1310 people, and in 2020, old patient visits again decreased to 1119 people. So, the problem in this study is that there is a $32 \%$ decrease in the interest in patient return visits at the Embun Pagi Gynecological Clinic in 2020. However, this data must receive more attention from the Embun Pagi Sekayu clinic management.

There was a decrease in visits from 2018 to 2020, possibly related to the shift of customers to other health facilities caused by word of mouth, so there is a possibility that interest in repeat visits is low (Maxham III, 2001). In addition, many factors influence patients to choose health services, such as brand strength, family references, experience, service comfort, the influence of word of mouth (Zhang et al., 2010). Customer dissatisfaction with the service offering results in low customer value (customer value) so that the benefits / perceived quality is less than the sacrifices made by consumers and make patients leave the clinic (Zhang \& Zhang, 2007; Karimi et al., 2018).

Based on the background of the problems described above, the formulation of the research problem, namely brand image and word of mouth, was based on the repurchase decision at Embun Pagi Sekayu Clinic and the results or conclusions of several studies on factors that affect performance (research gaps). This is shown from the findings regarding the differences in the word of mouth and brand image on patient decisions in choosing the Embun Pagi Sekayu obstetrics clinic (Cretu \& Brodie, 2007).

\section{Materials and Methods}

The design of this study is causal research, aiming to examine the cause and effect relationship between the independent variable word of mouth and brand image and the dependent variable of consumer decisions (Macdonald \& Sharp, 2000). In this study, the author uses several methods or techniques to ensure that the data that the author gets is the information needed for the study's final results. The sampling technique used in this study was random sampling, which is a sampling technique based on chance. Anyone who coincidentally/incidentally meets the research can be used as a sample if it is deemed that the person who happened to be met is suitable as a data source (Sugiyono, 2010; Phillippi \& Lauderdale, 2018; Porter et al., 2016; Holliday, 2010; Antin et al., 2015; Morse, 2015; Bengtsson, 2016). This type of survey research collects data and information to obtain facts and information regarding purchasing decisions from respondents using questionnaires. 


\section{Results and Discussions}

Respondents in this study were clinical patients examined at the Sekayu Embun Pagi Gynecological Clinic. The sample in this study was 100 patients using random sampling. The results of the analysis of the respondents' criteria are presented in the following tables:

Table 3

Research respondent data

\begin{tabular}{|c|c|c|c|}
\hline No & $\begin{array}{l}\text { Age } \\
\text { (Year) }\end{array}$ & $\begin{array}{l}\text { Frequency } \\
\text { (Person) }\end{array}$ & $\begin{array}{l}\text { Percentage } \\
(\%)\end{array}$ \\
\hline 1 & $<25$ & 30 & 30.0 \\
\hline \multirow[t]{2}{*}{2} & $>25$ & 70 & 70.0 \\
\hline & Total & 100 & 100 \\
\hline No & Domicile & $\begin{array}{l}\text { Frequency } \\
\text { (Person) }\end{array}$ & $\begin{array}{l}\text { Percentage } \\
(\%)\end{array}$ \\
\hline 1 & Sekayu Region & 74 & 74.0 \\
\hline \multirow[t]{2}{*}{2} & Outside Sekayu & 26 & 26.0 \\
\hline & Total & 100 & 100 \\
\hline No & Work & $\begin{array}{l}\text { Frequency } \\
\text { (Person) }\end{array}$ & $\begin{array}{l}\text { Percentage } \\
(\%)\end{array}$ \\
\hline 1 & Housewife & 20 & 20.0 \\
\hline 2 & Government employees & 30 & 30.0 \\
\hline 3 & Private employees & 30 & 30.0 \\
\hline \multirow[t]{2}{*}{4} & And others & 20 & 20.0 \\
\hline & Total & 100 & 100 \\
\hline No & Last education & $\begin{array}{l}\text { Frequency } \\
\text { (Person) }\end{array}$ & $\begin{array}{l}\text { Percentage } \\
(\%)\end{array}$ \\
\hline 1 & Senior High School & 60 & 60.0 \\
\hline 2 & Diploma & 20 & 20.0 \\
\hline \multirow[t]{2}{*}{3} & Bachelor & 20 & 20.0 \\
\hline & Total & 100 & 100 \\
\hline No & Monthly Income & $\begin{array}{l}\text { Frequency } \\
\text { (Person) }\end{array}$ & $\begin{array}{l}\text { Percentage } \\
(\%)\end{array}$ \\
\hline 1 & $<1,000,000$ & 40 & 40.0 \\
\hline 2 & $4,000,000-5,000,000$ & 45 & 45.0 \\
\hline \multirow[t]{2}{*}{3} & $>5,000,000$ & 15 & 15.0 \\
\hline & Total & 100 & 100 \\
\hline No & Complaints/Cases & $\begin{array}{l}\text { Frequency } \\
\text { (Person) }\end{array}$ & $\begin{array}{c}\text { Percentage } \\
(\%)\end{array}$ \\
\hline 1 & $\begin{array}{l}\text { Pregnancy Consultation } \\
\text { (USG) }\end{array}$ & 39 & 39.0 \\
\hline 2 & Pregnancy program & 11 & 11.0 \\
\hline 3 & Consul after giving birth & 7 & 7.0 \\
\hline 4 & Reproductive diseases & 8 & 8.0 \\
\hline 5 & $\mathrm{~KB}$ installation & 27 & 27.0 \\
\hline 6 & And others & 8 & 8.0 \\
\hline & Total & 100 & 100 \\
\hline
\end{tabular}

Source: Sekayu Embun Pagi Clinic Medical Record Report, 2021

Based on Table 3, the age of the respondents who dominated as many as 70 people aged $>25$ years with a percentage of $70 \%$. While the minority of respondents are aged $<25$ years, who are respondents with a total of 30 people or about $30 \%$. The domicile of the most respondents or the majority are respondents from the Sekayu area, amounting to 74

Ramadhayani B, R., Wahab, Z., Widiyanti, M., \& Rosa, A. (2022). The influence of word of mouth and brand image on the consumer decision process in choose clinic content: Case Study of Embun Pagi Sekayu Gynecological Clinic. International Research Journal of Management, IT and Social Sciences, 9(1), 110-118. https://doi.org/10.21744/irjmis.v9n1.2013 
people with a percentage of $74 \%$, while the respondents who are the minority are from outside Sekayu, amounting to 26 people with a percentage of $26 \%$.

The occupations of the most respondents or the majority are respondents who work as civil servants and private employees, amounting to 30 people with a percentage of $30 \%$, while the minority are respondents with homemakers and other jobs amounting to 20 people with a percentage of $20 \%$. The education level of the most respondents or the majority is respondents in the category of high school education level, amounting to 60 people with a percentage of $60 \%$. In comparison, the minority are respondents with a diploma and undergraduate education level category amounting to 20 people with a percentage of $20 \%$. The income of the most respondents or the majority is respondents with an income of 4,000,000 - 5,000,000, totaling 45 people with a percentage of $45 \%$, while the minority are respondents with an income $>5,000,000$ totaling 15 people with a percentage of $15 \%$.

\section{Data analysis}

Validity test

A validity test is used to measure whether or not a questionnaire is valid (Ghozali, 2011). The level of validity can be measured by comparing the value of calculated $r$ in (correlation item-total correlation) with the value of $r$ table ( $n-2)$ where $\mathrm{n}$ is the number of samples, the song used is $\mathrm{n}(100)-2=98$, resulting in an $\mathrm{r}$ table of 0.166 . If the $\mathrm{r}$ count is significant, it means that the statement is declared valid, and the following are the results of the calculation of the validity test using SPSS assistance.

Table 4

Validity test

\begin{tabular}{lcccc}
\hline Indicator & Item & r-Calculate & r-Table & Description \\
\hline Word of Mouth (X1) & 1 & 0.740 & 0.3610 & Valid \\
& 2 & 0.501 & 0.3610 & Valid \\
& 3 & 0.575 & 0.3610 & Valid \\
Brand Image (X2) & 4 & 0.653 & 0.3610 & Valid \\
& 5 & 0.407 & 0.3610 & Valid \\
& 6 & 0.486 & 0.3610 & Valid \\
& 7 & 0.750 & 0.3610 & Valid \\
& 1 & 0.681 & 0.3610 & Valid \\
& 2 & 0.642 & 0.3610 & Valid \\
& 3 & 0.677 & 0.3610 & Valid \\
& 4 & 0.732 & 0.3610 & Valid \\
& 5 & 0.400 & 0.3610 & Valid \\
& 6 & 0.587 & 0.3610 & Valid \\
& 7 & 0.505 & 0.3610 & Valid \\
& 8 & 0.551 & 0.3610 & Valid \\
& 1 & 0.677 & 0.3610 & Valid \\
& 2 & 0.652 & 0.3610 & Valid \\
& 3 & 0.748 & 0.3610 & Valid \\
& 4 & 0.745 & 0.3610 & Valid \\
& 5 & 0.748 & 0.3610 & Valid \\
\hline
\end{tabular}

Source: Sekayu Embun Pagi Clinic Medical Record Report, 2021

From table 4, it can be seen that the correlation between each indicator to the total construct score of each variable shows valid results. $\mathrm{R}$ count $>\mathrm{r}$ table so that it can be concluded that all statement items are declared valid.

\section{Reliability test}

A reliability test is used to test the extent to which the reliability of a measuring instrument can be used again for the same research. Reliability testing in this study is to use the formula Cronbach Alpha (a) variable is said to be reliable 
if it gives a value of $>0.60$ (Ghozali, 2011), and the following results of the calculation of the reliability test using SPSS assistance for each variable can be seen in the following table:

Table 5

Reliability test results

\begin{tabular}{lcccc}
\hline Variable & $\begin{array}{c}\text { Cronbach's } \\
\text { Alpha }\end{array}$ & Cut Off & $\begin{array}{c}\text { Nof } \\
\text { Items }\end{array}$ & Description \\
\hline Word of Mouth (X1) & 0.830 & $>0.60$ & 7 & Reliable \\
Brand Image (X2) & 0.851 & $>0.60$ & 8 & Reliable \\
Consumer Decision (Y) & 0.880 & $>0.60$ & 5 & Reliable \\
\hline
\end{tabular}

Source: Sekayu Embun Pagi Clinic Medical Record Report, 2021

The reliability test results indicate that all variables have a reliable Alpha coefficient so that, furthermore, the items in each of these variable concepts are worthy of being used as benchmarks or parameters.

The influence of word of mouth on consumer decisions in choosing an obstetrics clinic (Case Study at Embun Pagi Sekayu Gynecological Clinic)

From the study results, the word of mouth variable $\left(\mathrm{X}_{1}\right)$ has a beta value of 0.276 with a significant value of 0.000 $<0.05$. This shows that the word of mouth variable has a positive and significant influence on consumer decisions in choosing an obstetrics clinic (Case Study at Embun Pagi Sekayu Gynecological Clinic). This proves that the first hypothesis on the variable word of mouth has a positive and significant effect and can be accepted.

The results of this study are supported by Rosiana (2011), showing that WOM has three dimensions: positive stories, recommendations, and invitations. Likewise, the results of previous research conducted by Voyer \& Ranaweera (2015), entitled "The impact of word of mouth on purchasing decisions. Researching the risk and interaction of bonding strength and involvement" concluded that word of mouth had a significant positive effect on consumer purchasing decisions (Martin \& Lueg, 2013).

The effect of brand image on consumer decisions in choosing an obstetrics clinic (Case Study at Embun Pagi Sekayu Gynecological Clinic)

The study results indicate that the brand image variable $\left(\mathrm{X}_{2}\right)$ has a beta of 0.430 with a significance value of 0.000 which is $<0.05$. This shows that the brand image variable has a positive and significant influence on consumer decisions in choosing an obstetrics clinic (Case Study at Embun Pagi Sekayu Gynecological Clinic). This proves that the second hypothesis on the variable brand image has a positive and significant effect and can be accepted (Wesley et al., 2006; Aguirre-Rodriguez et al., 2012).

The results of this study are supported by Keller (2015), showing that Brand Image has three components, namely: Corporate Image (corporate image), Product Image (product image), and User Image (user image). Moreover, the results of previous research conducted by (Sutiyono \& Hadibrata, 2020) show that brand image has a positive and significant effect on purchasing decisions.

\section{Conclusion}

a) Simultaneous test results (F-test) show that the variables Word Of Mouth and Brand Image have a positive and significant effect on consumer decision variables in choosing a Gynecological Clinic (Case Study at Embun Pagi Sekayu Gynecological Clinic).

b) The partial test results (t-test) show that Word of Mouth and Brand Image positively and significantly affect consumer decision variables in choosing a Gynecological Clinic (Case Study at Embun Pagi Sekayu Gynecological Clinic).

c) The result of the coefficient of determination $\left(\mathrm{R}^{2}\right)$ shows the value of $\mathrm{R}$ Square of 0.644 , which means the consumer decision variables can be explained by word of mouth and brand image of $64.4 \%$, and the remaining $35.6 \%$ is explained by other variables that are not described in this research.

Ramadhayani B, R., Wahab, Z., Widiyanti, M., \& Rosa, A. (2022). The influence of word of mouth and brand image on the consumer decision process in choose clinic content: Case Study of Embun Pagi Sekayu Gynecological Clinic. International Research Journal of Management, IT and Social Sciences, 9(1), 110-118. https://doi.org/10.21744/irjmis.v9n1.2013 
Conflict of interest statement

The authors declared that they have no competing interests.

Statement of authorship

The authors have a responsibility for the conception and design of the study. The authors have approved the final article.

Acknowledgments

The author expresses his deep gratitude to the academic parties who have provided support in the form of feedback. 


\section{References}

Aguirre-Rodriguez, A., Bosnjak, M., \& Sirgy, M. J. (2012). Moderators of the self-congruity effect on consumer decision-making: A meta-analysis. Journal of Business Research, 65(8), 1179-1188. https://doi.org/10.1016/j.jbusres.2011.07.031

Antin, T. M., Constantine, N. A., \& Hunt, G. (2015). Conflicting discourses in qualitative research: The search for divergent data within cases. Field Methods, 27(3), 211-222.

Bengtsson, M. (2016). How to plan and perform a qualitative study using content analysis. NursingPlus Open, 2, 814. https://doi.org/10.1016/j.npls.2016.01.001

Cretu, A. E., \& Brodie, R. J. (2007). The influence of brand image and company reputation where manufacturers market to small firms: A customer value perspective. Industrial marketing management, 36(2), 230-240. https://doi.org/10.1016/j.indmarman.2005.08.013

Ghozali, I. (2011). Aplikasi Analisis Multivariate Program IBM SPSS 19. Badan Penerbit UNDIP: Semarang.

Holliday, A. (2010). Analysing qualitative data. Continuum companion to research methods in applied linguistics, 98110.

Karimi, S., Holland, C. P., \& Papamichail, K. N. (2018). The impact of consumer archetypes on online purchase decision-making processes and outcomes: A behavioural process perspective. Journal of Business Research, 91 , 71-82. https://doi.org/10.1016/j.jbusres.2018.05.038

Keller, G. (2015). Statistics for Management and Economics, Abbreviated. Cengage Learning.

Macdonald, E. K., \& Sharp, B. M. (2000). Brand awareness effects on consumer decision making for a common, repeat purchase product: A replication. Journal of business research, 48(1), 5-15. https://doi.org/10.1016/S01482963(98)00070-8

Mahatama, A. A. B. P., \& Wardana, M. (2021). The role of brand image and customer commitment in mediating service quality towards customer loyalty. International Research Journal of Management, IT and Social Sciences, 9(1), 79-89. https://doi.org/10.21744/irjmis.v9n1.2006

Martin, W. C., \& Lueg, J. E. (2013). Modeling word-of-mouth usage. Journal of Business Research, 66(7), 801-808. https://doi.org/10.1016/j.jbusres.2011.06.004

Maxham III, J. G. (2001). Service recovery's influence on consumer satisfaction, positive word-of-mouth, and purchase intentions. Journal of business research, 54(1), 11-24. https://doi.org/10.1016/S0148-2963(00)00114-4

Meitridasari, U., Wahab, Z., Isnurhadi, I., \& Widiyanti, M. (2021). Effect of instagram and celebrity endorser on purchasing motive of le minerale packaging water with image brand as intervention variables. International Research Journal of Management, IT and Social Sciences, 8(1), 123-131. https://doi.org/10.21744/irjmis.v8n1.1175

Morse, J. M. (2015). Critical analysis of strategies for determining rigor in qualitative inquiry. Qualitative health research, 25(9), 1212-1222.

Phillippi, J., \& Lauderdale, J. (2018). A guide to field notes for qualitative research: Context and conversation. Qualitative health research, 28(3), 381-388.

Porter, W. W., Graham, C. R., Bodily, R. G., \& Sandberg, D. S. (2016). A qualitative analysis of institutional drivers and barriers to blended learning adoption in higher education. The internet and Higher education, 28, 17-27. https://doi.org/10.1016/j.iheduc.2015.08.003

Sääksjärvi, M., \& Samiee, S. (2011). Relationships among brand identity, brand image and brand preference: differences between cyber and extension retail brands over time. Journal of interactive marketing, 25(3), 169-177. https://doi.org/10.1016/j.intmar.2011.04.002

Sugiyono, D. (2010). Metode penelitian kuantitatif dan R\&D. Bandung: Alfabeta.

Sutiyono, R., \& Hadibrata, B. (2020). The Effect Of Prices, Brand Images, And After Sales Service Reinforced Bar Steel Products On Consumer Purchasing Decisions Of PT. Krakatau Wajatama Osaka Steel Marketing. Dinasti International Journal of Education Management And Social Science, 1(6), 947-967.

Voyer, P. A., \& Ranaweera, C. (2015). The impact of word of mouth on service purchase decisions: Examining risk and the interaction of tie strength and involvement. Journal of Service Theory and Practice.

Wesley, S., LeHew, M., \& Woodside, A. G. (2006). Consumer decision-making styles and mall shopping behavior: Building theory using exploratory data analysis and the comparative method. Journal of Business Research, 59(5), 535-548. https://doi.org/10.1016/j.jbusres.2006.01.005

Zhang, J. Q., Craciun, G., \& Shin, D. (2010). When does electronic word-of-mouth matter? A study of consumer product reviews. Journal of Business Research, 63(12), 1336-1341. https://doi.org/10.1016/j.jbusres.2009.12.011

Ramadhayani B, R., Wahab, Z., Widiyanti, M., \& Rosa, A. (2022). The influence of word of mouth and brand image on the consumer decision process in choose clinic content: Case Study of Embun Pagi Sekayu Gynecological Clinic. International Research Journal of Management, IT and Social Sciences, 9(1), 110-118. https://doi.org/10.21744/irjmis.v9n1.2013 
Zhang, T., \& Zhang, D. (2007). Agent-based simulation of consumer purchase decision-making and the decoy effect. Journal of business research, 60(8), 912-922. https://doi.org/10.1016/j.jbusres.2007.02.006 